\title{
Filhos do paraíso: a ética no mundo infantil
}

Glacy Queiros de Roure*

Neisi Maria da Guia Silva**

\begin{abstract}
Resumo
O propósito deste estudo é perceber a experiência da infância no filme Filhos do paraíso (1997). Um filme iraniano, dirigido por Majid Majidi, com direçáo de fotografia de Parviz Malekzaade, baseado em fatos reais, que nos conta a história de dois irmáos, Ali ( 9 anos) e Zahra (6 anos), os quais dividem um mesmo par de tênis para ir à escola. Muitas questóes são tratadas no filme mostrando-nos o olhar da criança que a todo tempo se mostra solidária e capaz de se posicionar perante as dificuldades que a vida lhes apresenta. O espaço geográfico é o da periferia, que retrata bem os problemas de infraestrutura. Sáo também levantadas questóes humanísticas relativas ao amor, à ética, à honestidade, à solidariedade e ao companheirismo. Encontramos nessa família, e nos personagens coadjuvantes, importantes reflexóes nesse sentido, principalmente sobre a dignidade no enfrentamento da pobreza e do sonho com um futuro melhor. Ainda é possível observar na película a importância do pai e dos vínculos afetivos na constituiçáo do sujeito.

Palavras-chave: cultura, arte, cinema, infantil, psicologia.
\end{abstract}

\section{Children of heaven: ethics in the children's world}

\begin{abstract}
The purpose of this study is to understand the experience of the childhood in the movie Children of Heaven (1997). An Iranian movie directed by Majid Majidi, photography direction by Parviz Malekzaade, based on real facts, which tells the story of two brothers, Ali (9 years old) and Zahra (6 years old), who share the same pair of shoes to go to school. Many issues are addressed in the movie, showing us the child look that all the time is solidary and able to stand before the difficulties that life presents. The geographic space is the periphery, which shows the infrastructure problems. They are also raised humanistic issues related to love, ethics, honesty, solidarity and companionship. We found in this family, and supporting characters, important considerations in this regard, particularly on the dignity in the face of poverty and dream of a better future. It is still possible observer in the movie the importance of the father and the emotional bonds in the constitution of the subject.
\end{abstract}

Keywords: culture, art, cinema, infant, psychology.

* Doutora em Estudos Linguísticos pela Unicamp. Professora da Pontifícia Universidade Católica de Goiás. E-mail: glacyy@terra.com.br.

** Doutoranda em Educação pela PUC/Goiás. Professora da Universidade Federal de Goiás. E-mail: neisimaria7@gmail.com. 


\section{Introduçáo}

Este texto está vinculado às discussóes do Grupo de Estudos e Pesquisa: Educação, Infância, Arte e Psicanálise (Gepeiap), constituído desde 2012. O grupo é composto por professores, estudantes e pesquisadores da Pontifícia Universidade Católica de Goiás - PUC-GO; da Universidade Federal de Goiás - UFG (Faculdade de Educação - FE; e Centro de Ensino e Pesquisa Aplicada à Educaçáo - Cepae) e da Universidade Estadual de Goiás - UEG (Campus de Montes Belos). O grupo objetiva discutir e problematizar o tempo da infância em diferentes áreas do conhecimento: educaçáo, arte, psicanálise, filosofia, sociologia. Tem como proposta a investigaçáo de elementos (in)visíveis que constituem uma infância, concebida como instância de estruturação do sujeito, de um sujeito como efeito de linguagem, suportado por um desejo que não seja anônimo (GEPEIAP, 2016).

Tendo em vista tais pressupostos, o propósito deste texto é refletir sobre a experiência da infância no filme Filhos do paraíso (Bacheha-Ye aseman, 1997), um filme iraniano, dirigido por Majid Majidi, cuja obra tem como princípio refletir sobre a intolerância e sobre o estranhamento entre os povos. A fotografia do filme é dirigida por Parviz Malekzaade e a música, por Keivan Jahanshahi. Ele é baseado em fatos reais e nos conta a história de duas crianças, Ali (Amir Farrokh Hashemian), com nove anos, e Zahra (Bahare Seddiqi), com seis anos, que dividem o mesmo par de tênis para ir à escola. $\mathrm{O}$ filme retrata a experiência de companheirismo e solidariedade vivida entre os irmáos e possibilita a reflexão sobre a existência de uma dimensáo ética no mundo dito infantil.

Em relaçáo ao cinema iraniano, Meleiro (2006) informa-nos da existência de três gêneros fílmicos: o modelo hollywoodiano, o cinema autor e o cinema político militante. Atualmente, $20 \%$ das obras produzidas no Irã se dedicam a tratar da consciência social, estabelecendo uma autocrítica relacionada às questóes da realidade do país, fato que muitos consideram uma "arma política". A proposta é levar o público a refletir sobre a realidade em que vivem naquele país:

A ideologia do cinema político está diretamente implicada na película, já que as narrativas atuam para resolver simbolicamente contradiçóes sociais e devem lidar com as divisóes políticas existentes entre os grupos, classes ou sexos, que foram construídas como naturais ou inevitáveis na nossa sociedade. (MELEIRO, 2006, p. 79). 
Com certeza, o cinema iraniano nos proporciona um olhar mais ampliado do que seja o Irã e que vai além do revelado pelas grandes redes de comunicação, limitadas aos informes sobre conflitos ocorridos no país e à reproduçáo de estereótipos que limitam o nosso entendimento sobre a cultura iraniana. Nos filmes, os temas próximos ao cotidiano ou mais complexos, como aqueles que tratam de tabus relativos aos códigos islâmicos e a regras de conduta, sáo tratados com reflexáo, poesia e arte.

$\mathrm{Na}$ história do cinema iraniano, encontramos uma vasta produção cinematográfica que nos permite bordejar de forma singular o (in)visível e o (in)transmissível que cerca a experiência da infância e, assim, pode iluminar a existência de uma outra infância (ROURE 2014). Nessa filmografia, encontramos obras-primas de grandes diretores, os quais se apresentam como referência tanto na área dos estudos fílmicos como nos estudos sobre a infância. Quais sejam: Onde fica a casa do meu amigo? (Khane-ye Doust Kodjast? 1987) e Tarefa de casa (Mashgh-e Shab, 1989), de Abbas Kiarostami; O silêncio (Sokout, 1997), de Mohsen Makhmalbaf; $A$ maçã (Sib, 1997), O quadro negro (Takhté Siah, 1999) e Cavalo de duas pernas (Asbe Du-pa, 2008), de Samira Makhmalbaf; $O$ baläo branco (Badkonake Sefid, 1995) e O espelho (Ayeneh, 1997), de Jafar Panahi; Filhos do paraiso (Bacheha-Ye Aseman, 1997), A cor do paraiso (Rang-e Khoda, 1998), Baran (Baran, 2001) e A Canção dos pardais (Avaze Gonjeshk-Ha, 2008), de Majid Majidi; Tempo de embebedar cavalos (Zamani Barayé Masti Asbha, 2000), Tartarugas podem voar (Lakposhtha Parvaz Mikonand, 2004) e (Life on the Border, 2015), de Bahman Ghobadi.

Em quase todos esses filmes, as crianças ou os adolescentes são apresentados como protagonistas e se, de modo geral, eles sáo utilizados pelos diretores como metáforas para a realização de uma crítica social (MELEIRO, 2006), os filmes, por eles mesmos, em razáo dos procedimentos estéticos utilizados, acabam por revelar um modo de ser criança, quase sempre, (in)visível aos estudiosos da infância. Neles, a criança ou o adolescente protagonista, mais que reproduzir narrativas próprias ao mundo já conhecido da infância, instiga, com um modo ético de se colocar no mundo, a reflexão sobre nossa condiçáo humana.

Observamos, nesses filmes, uma condiçáo de resiliência diante dos acontecimentos vividos, uma capacidade mimética de recriar os acontecimentos adversos e um modo ético de presença do sujeito no mundo: seja como "mulas", ou melhor, como contrabandistas, trabalhadoras comprometidas em auxiliar a família no seu sustento, como em Quadro negro 
(Takbté Siah, 1999), seja como aquele que percorre a vila incansavelmente à procura do amigo para devolver o caderno trocado, na sala de aula, para que esse náo seja expulso da escola, como em Onde fica a casa do meu amigo? (Khane-ye Doust Kodjast? 1987), seja como as crianças refugiadas nos campos de Kobani e Shengal, fronteira da Síria e do Iraque, no documentário Life on the Border (2015), em que elas próprias denunciam os brutais ataques do Estado Islâmico do Iraque e da Síria (ISIS).

O filme que vamos analisar, Filhos do paraiso (Bacheha-Ye Aseman, 1997), considerado pela crítica como uma lição de amor, conquistou três prêmios no Festival Mundial de Filmes em Montreal, em 1997, e foi produzido pelo Idica. É baseado em uma história real de dois irmáos, Ali e Zahra, que dividem um mesmo par de tênis para ir à escola. A família mora em um bairro pobre, ao sul de Teerã, e é marcada pela pobreza, pois enfrenta dificuldades para comprar alimentos e pagar o aluguel. Contudo, apesar disso, é possível observar, nas relaçóes familiares, a importância do pai e a existência de vínculos afetivos como o amor, o respeito, o companheirismo e a solidariedade. Além do mais, o filme retrata, por parte da família, uma dignidade no enfrentamento da pobreza.

Vale ainda destacar a brilhante atuaçáo dos atores Ali (Amir Farrokh Hashemian) e Zahra (Bahare Seddiqi), selecionados, à época, por Majid Majidi em escolas da regiáo.

\section{Em cena: Filhos do paraíso, de Majid Majidi}

No filme, o desenvolvimento de toda a trama parte de uma situaçáo-problema inicial vivida pelos irmáos e suas tentativas para solucioná-la. Os sapatos velhos de Zahra foram consertados e ficou a cargo de Ali buscá-los. Ele pega os sapatos, mas no caminho de volta para casa, enquanto passava para comprar algumas batatas, deposita a sacola plástica com os sapatos de Zahra entre os caixotes do pequeno armazém. Envolvido na escolha das batatas, ele náo percebe que o catador de lixo recolhe a sacola plástica e, assim, Ali perde de vista o único par de sapatos da irmá e volta para casa.

Depois do incidente, aos prantos, ele conta o ocorrido para a irmá que se apresenta desolada. Desse momento em diante, ambos viverão o dilema de contar, ou não, o ocorrido ao pai (Mohammad Amir Naji). A questáo é que, para Ali, o pai, em função das dificuldades em pagar o mer- 
cado e o aluguel, já vencido há cinco meses, não terá dinheiro para comprar outro sapato para a irmá.

Nesse filme, ao lado da preocupaçáo de Ali com uma possível bronca do pai, é possível observar uma disponibilidade subjetiva do menino em aceitar como fato a impossibilidade paterna de responder a qualquer demanda que, naquele momento, implicasse em algum gasto: "Não estou com medo de apanhar. Papai náo terá dinheiro até o fim do mês. Ele terá que pedir algum emprestado". O que náo significou, por parte de Ali, desconsiderar ou desqualificar a posição do pai como autoridade paterna.

O pai de Ali e Zahra é apresentado no filme como um homem humilde, com princípios rígidos, religioso e honesto, o que fica evidente em várias cenas do filme. Apesar de aparentemente rude, ele parece sempre preocupado com a saúde da mulher, com a educaçáo dos filhos e sonha com um futuro melhor. Como patriarca da família, ele procura transmitir valores como amor, respeito e honestidade.

Em relação ao papel do pai na constituição psíquica, Lacan (1995), com a releitura de Freud, contrapóe-se a uma visão reducionista do Édipo como drama familiar e o considera como função estruturante, deslocando-o de uma visão relacionada à família nuclear burguesa do tipo patriarcal. Nesse sentido, a noçáo de pai é menos a de um ser encarnado do que o de uma entidade essencialmente simbólica que ordena uma funçáo. É em razáo da preeminência dessa existência simbólica que pensamos no seu caráter fundamentalmente operante e estruturante em nosso psiquismo, "em outras palavras, é porque esse pai simbólico é universal - daí a essência de sua necessidade -, que nós não podemos deixar de ser tocados pela incidência de sua função, que estrutura nosso ordenamento psíquico. (LACAN, 1999, p. 154).

Lacan (1999) ainda reafirma a função do pai como simbólica e define o significante "nome do pai" como aquele que dá esteio e promulga a lei e cuja função consiste na regulação do sujeito com seu desejo ao conjunto dos significantes que o regem. Nesse texto, Lacan náo só aproxima o significante "nome do pai" ao complexo de Édipo, mas ressalta a existência de uma articulaçáo lógica entre eles. É no interior do complexo de Édipo que o "nome do pai" se fará presente: "Não se coloca a questão do Édipo se não houver pai; inversamente falar de Édipo é introduzir como essencial a função do pai" (LACAN, 1999, p. 171).

Dependerá da incidência do significante "nome do pai" na vida do sujeito para que nela se produza, ou não, um sujeito de desejo. "Em outras 
palavras, é preciso ter 'Nome do Pai', mas é também preciso que saibamos servir-nos dele. É disso que o destino e o resultado de toda a história podem depender muito" (LACAN, 1999, p. 163).

Pensar uma família em situação de exclusão econômica, como a de Ali e Zahra, em uma cultura capitalista, marcada pelo individualismo e pelo consumo, implica considerar o peso de uma discursividade que, apoiada sobre a acumulaçáo de bens, promove um deslocamento do ser para o ter. Nesse contexto, a garantia de um lugar a ser ocupado pelo sujeito encontra-se náo mais determinada pelos valores, obrigaçóes e tradiçóes, com base nos quais se anunciam os ideais a ser cumpridos na sociedade, mas tem como referência os bens que o sujeito tem ou aquilo que ele parece ser. $\mathrm{O}$ náo cumprimento do imperativo em ter produz efeitos imediatos em relaçáo à figura paterna. Esses efeitos foram denominados por Lacan (1993) de "declínio da função paterna", isso porque, uma vez que o pai náo seja reconhecido socialmente, não se apresenta como um consumidor em potencial, por exemplo, é quase impossível que ele ocupe um lugar simbólico para o filho.

Que o valor do sujeito suspenso à sua riqueza exibida, por exemplo, destitui de possível paternidade quem está na pobreza - coisa mais grave e mais geral -, deixa prevalecer o real dos laços que organizam a nossa vida social, pois ser alguém náo parece ser o efeito de um nome, mas o efeito da possessão real das coisas [...]. (CALLIGARIS, 1991, p. 118).

No caso da família de Ali, a situaçáo de pobreza em que ela se encontra submetida, pelo fato de o pai não ter um bom salário e de não poder atender a uma demanda de consumo de objetos, não afeta a função paterna exercida por ele. $\mathrm{Na}$ verdade, sem que disso tenha consciência, Ali poupa o pai de uma situaçáo que o exporia em sua miséria: náo ter dinheiro para comprar o sapato, sem, no entanto, desqualificá-lo. O que se coloca para Ali é, então, sua responsabilização pela perda dos sapatos. Desse modo, o que orienta sua decisão parece ser menos o medo de uma bronca e mais uma inarredável posiçáo ética vinculada a uma necessária açáo, em que ele náo recua diante do preço a pagar.

Assim, ainda que esse filme seja normalmente concebido como uma liçáo de amizade e companheirismo entre os irmáos e quase nada seja dito em relação à figura paterna, é com base nos procedimentos estéticos utilizados que podemos perceber a sua importância no decorrer de todo o filme. Quase sempre enquadrado em posiçóes centralizadas pelo diretor de 
fotografia, o pai caracteriza-se como elemento chave na conduçáo de toda a narrativa fílmica. Lembremos que é em função da relação que Ali estabelece com esse grande Outro - o pai - que um ato de desejo será realizado.

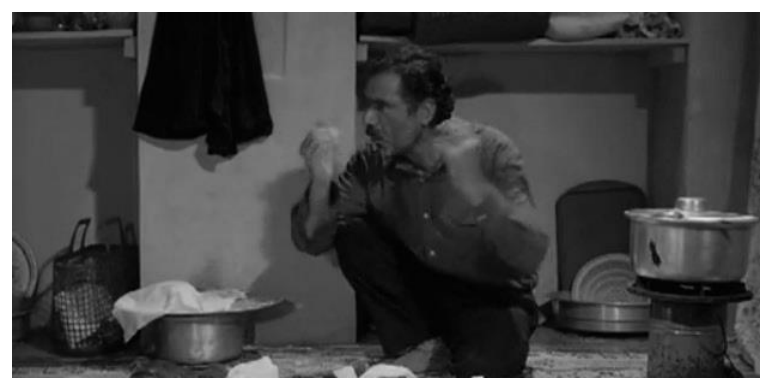

Figura 1 - Pai de Ali em casa

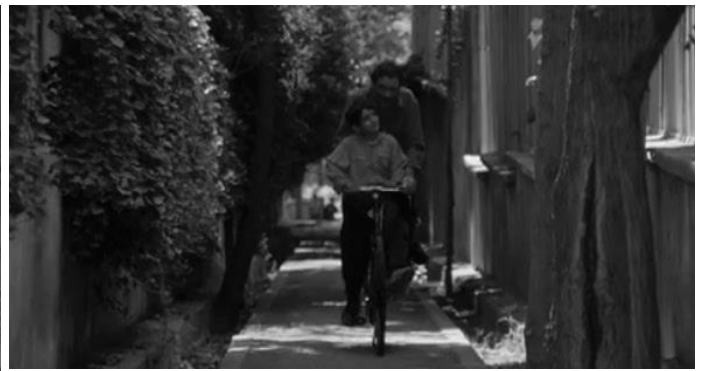

Figura 2 - Ali e o pai na bicicleta

\section{Uma decisáo, um pacto silencioso}

Será a partir da sugestáo dada por Ali que os irmáos passaráo a revezar o único par de sapatos disponível, ou seja, o seu velho tênis, que logicamente ficou enorme para Zahra. Ainda que desconcertada com o uso do tênis, a irmá mantém-se fiel a ele, a quem dedica amor e companheirismo, além de lhe depositar imensa confiança. É a presença do carinho e da cumplicidade dos dois irmáos, em torno de um pacto que náo pode ser revelado, que faz do filme uma poesia.

Nesse sentido, vale retomarmos a cena em que a decisão da partilha é tomada em segredo por ambos, ainda que ela ocorra na frente dos pais. É noite e a família encontra-se reunida em frente à televisão, enquanto o pai corta o açúcar para o chá que será servido na Mesquita. A conversa entre os pais gira em torno da saúde da máe e da falta de dinheiro para o pagamento da venda e do aluguel que se encontram atrasados, o aluguel há mais de cinco meses.

Enquanto isso, os irmãos travam um silencioso diálogo mediado pela troca de cadernos. Nesse momento, observamos uma transiçáo do plano conjunto para o plano individual e a câmera volta-se para os corpos de Ali e Zahra que se encontram sentados no chăo sobre seus tapetes. Em seguida, a câmera desce em plongée tomando em primeiro plano apenas seus cadernos e suas máos. Para dar ênfase a esse diálogo, o diretor situa a troca de cadernos entre os irmáos ao longo de uma longa sequência estruturada pela relação campo-contracampo, de modo que o visível (campo) e o invisível (contracampo) váo trocando de lugar nos dois lados do dispositivo especular. $\hat{E}$ 
da articulaçáo do campo visível (o caderno e mãos de Zahra) com o campo ausente (o mesmo caderno e as mãos de $\mathrm{Ali}$ ) que as perguntas e respostas são escritas e trocadas entre os irmãos. Ao final, em face da hesitação de Zahra em escrever sua posiçáo final, a câmera focaliza, em um mesmo plano, as máos de Zahra sobre o caderno e as máos de Ali oferecendo seu lápis como forma de agradecimento.

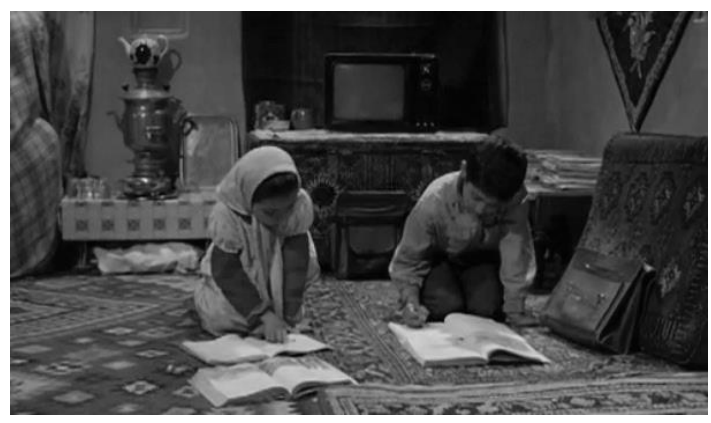

Figura 3 - Zahra e Ali sentados no chão

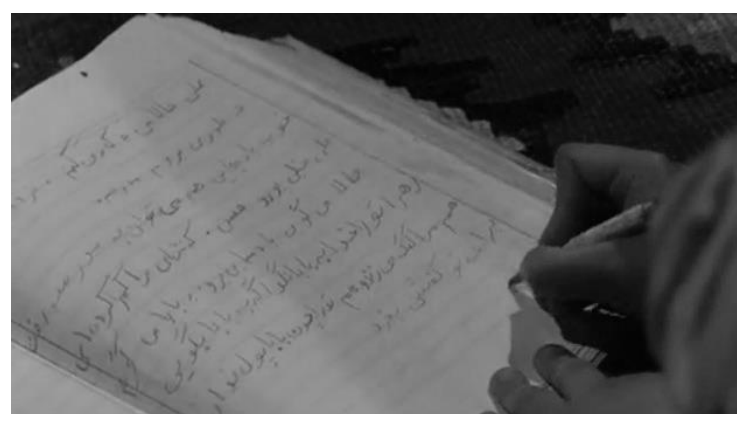

Figura 4 - Zahra escrevendo para Ali

Uma vez estabelecido o acordo, eles assumem para si a responsabilidade do ocorrido e, desse momento em diante, vivem o drama do compartilhamento do par de sapatos: Zahra usará o tênis de manhá e o devolverá a Ali para que ele possa ir às aulas no período da tarde.

Com o objetivo de ressaltar a cumplicidade e o companheirismo entre os irmáos, o expectador é convocado a observar um longo plano sequência (quase dois minutos) com a cena da corrida de Zahra pela vila iraniana com seus estreitos corredores até o encontro com o irmáo, a troca de sapatos e depois a corrida de Ali até a escola.

Essa cena, que é reintroduzida pelo diretor por mais de uma vez, permitirá ao espectador pensar na condição resiliente dos irmãos em face dessa experiência realizada em tamanha adversidade. Tal característica parece compor principalmente o personagem de Ali e nos ajuda a pensar o quanto a resiliência é incondicionalmente presente nas crianças.

Logo após o primeiro dia da troca de sapatos, Zahra confessa a Ali que não irá mais a aula com o tênis porque está muito sujo. Nesse momento, vemos uma das cenas mais belas do filme. Tendo ao fundo um muro descascado, o que denota a condiçáo de pobreza da família, Ali e Zahra encontram-se sentados sobre um pequeno poço lavando o tênis. De repente, sem querer, Ali sopra parte da espuma que recobre o tênis. Vendo o gesto de Ali, Zahra o repete e produz bolhas de sabão que saltam no ar. Daí em diante, com desta- 
que para suas expressóes faciais, os dois sáo filmados em primeiro plano, ambos com suas bolhas de sabão até que elas - as bolhas - ao som de uma bela trilha sonora, parecem adquirir vida e dançam sozinhas pelo campo fílmico.

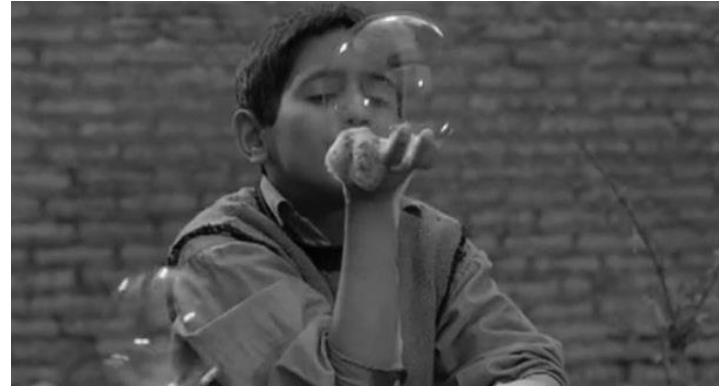

Figura 5 - Ali fazendo bolhas

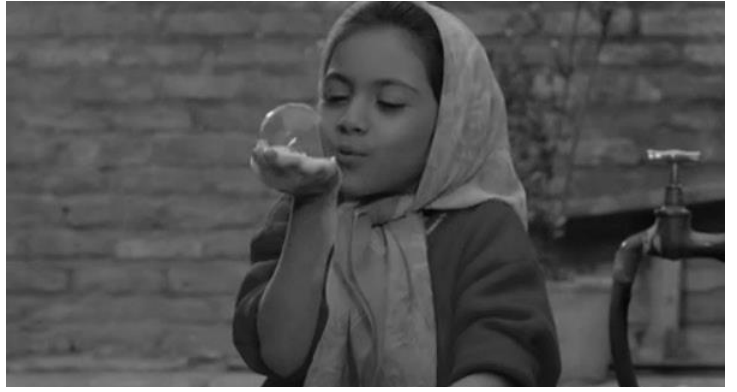

Figura 6 - Zahra imitando Ali

Para pensarmos nessa capacidade mimética, apresentada pela criança quando transforma o nada em tudo, produzindo caminhos e restabelecendo desordens, nada melhor que retomarmos as reflexóes de Walter Benjamin sobre a mímesis e o universo infantil:

Elas [as crianças] sentem-se irresistivelmente atraídas pelos destroços que surgem da construçáo, do trabalho no jardim ou em casa, da atividade do alfaiate ou do marceneiro. Nesses restos que sobram elas reconhecem o rosto que o mundo das coisas volta exatamente pra elas e, só para elas. Nesses restos elas estáo mais empenhadas em imitar as obras dos adultos do que em estabelecer entre os mais diferentes materiais, através daquilo que criam em suas brincadeiras, uma nova e incoerente relaçáo. Com isso as crianças formam seu próprio mundo de coisas, mundo pequeno inserido em um mundo maior. (1984, p. 77).

Assim, se a experiência da criança difere da experiência do adulto é porque a relaçáo deste com o mundo pauta-se pelo predomínio da razáo, o que pressupóe o controle e a reflexão, ao passo que a criança, cuja relação com o mundo é marcada pelo "(im)possível”, o apreende com "a sensibilidade e imaginação" (SCHLESENER, 2009, p. 154). Desse modo, é por se sentir à vontade no mundo que ela é capaz de produzir experiências de (re) apropriaçáo e renovaçáo de sentidos, sempre reveladoras de sua condiçáo sensível. É a capacidade mimética da criança que lhe permite se debruçar sobre todo e qualquer objeto e ousar na produção de significaçóes lógicas e ilógicas, contornando a experiência traumática da existência. Como destaca Benjamin (1987, p. 229): as "crianças decretam a renovação da existência por meio de uma prática centuplicada e jamais complicada". 


\section{O sapato cor-de-rosa}

No decorrer do filme, inúmeras são as cenas em que a câmera se volta para a imagem de sapatos, lembrando ao espectador a problemática da trama. Será assim que, um dia, no intervalo da aula, Zahra verá na escola uma colega com o sapato cor-de-rosa que Ali havia perdido. Ao término da aula, ela segue a garota para descobrir onde ela mora e conta ao irmáo. Ao chegarem à casa da menina, Ali e Zahra se veem impossibilitados de intervir, uma vez que se deparam com o pai da colega recebendo ajuda dela, porque ele é deficiente visual, para carregar um tabuleiro de doces para vender.

Comunicando-se apenas pelo olhar, visto que as duas crianças náo trocam nem uma palavra, elas entendem a impossibilidade de resgatar o sapato e voltam para casa. Mesmo passando por tantos transtornos, elas náo conseguem se dirigir à família da colega de Zahra. Há um impossível a ser dito, a ser comunicado diante do estado de miséria em que essa família se apresenta.

No outro dia, quando Zahra voltava para casa correndo para entregar os sapatos, deixou cair a caneta que ganhara do irmáo. O objeto é encontrado pela mesma colega do dia anterior que grita para Zahra, mas não consegue ser ouvida. Apesar de tentar alcançar Zahra para devolver o objeto, ela náo conseguiu e, assim, pôde apreciar a caneta. A colega poderia se aproveitar do descuido e ficar com a caneta, mas isto náo ocorre; mesmo tendo se encantado pelo objeto, no dia seguinte, ela devolve a caneta a Zahra.

De modo geral, a ética não é concebida como inata, daí a necessidade de ser aprendida no processo educativo, a fim de que a criança, aos poucos, apresente uma natureza moral que supere sua própria natureza instintiva. É por isso que a família e a escola sáo consideradas como ambientes apropriados para a transmissáo e o aprendizado de valores éticos e morais.

Em um tempo marcado pelo individualismo, cada vez mais presente, é comum observarmos uma discursividade que reitera a importância do ensino da Moral e da Ética para crianças desde cedo. Lembramos que, segundo Piaget, o desenvolvimento pleno da moralidade infantil só ocorre entre os dez e onze anos com a passagem do princípio de heteronomia para a autonomia (PIAGET, 1994). Mas o que significa afirmar a existência de um "desenvolvimento" moral na criança e a necessidade do ensino da Ética na escola? Ainda que seja impossível discordar de tal proposta, pensamos que tal pressuposto, no limite, não só retira da criança uma condiçáo muito própria de interpretar e de se indignar com o mundo dos adultos, mas também a coloca numa con- 
diçáo absurda de dependência dos significados que regem o mundo adulto e de suas consequentes interpretaçóes.

Uma vez que, neste texto, reconhecemos o quanto a arte possibilita-nos bordejar o (ir)representável e o (in)visível da/na infância (GEPEIAP, 2016), nesse filme, o respeito, a tolerância e a responsabilidade, demonstrados por Ali no decorrer de todo o filme e por Zahra ou pela coleguinha da escola, podem nos ajudar a pensar a existência de uma outra criança, de uma outra infância. Uma infância que se apresenta imersa no campo da linguagem e que, por isso mesmo, traz consigo a possibilidade de fazer experiência e apresentar outros significados que náo sejam a esperteza ou o desrespeito - táo comuns ao mundo adulto - e que dizem de sua indignaçáo com esse mundo. Aliás, é por não se encontrar totalmente submetida aos significados do mundo adulto que essa criança pode "olhar" o que já não pode ser "visto" e, assim, produzir atos éticos que se comprometam com um mundo mais ético e humano (ROURE; SÁ, 2015).

Em outra cena, o pai de Ali e Zahra recebe de um amigo da mesquita uma máquina para borrifar árvores e decide que, juntamente com Ali, irá procurar casas em que possa oferecer seu trabalho como jardineiro, na tentativa de ganhar algum dinheiro extra. $\mathrm{Na}$ bicicleta do pai, os dois chegam a um bairro de famílias mais abastadas ao norte de Teerá. Diante das dificuldades do pai em falar no interfone, Ali se propóe a ajudá-lo. Após várias tentativas, eles conseguem um jardim para cuidar e enquanto o pai trabalha, o menino brinca com o neto do dono da casa. Ao saírem da casa, o pai, orgulhoso com o dinheiro recebido pelo trabalho realizado, passa a compartilhar com o filho os sonhos de que esse novo trabalho possa ajudá-los no orçamento familiar.

Desse modo, diante das dificuldades do pai, mais uma vez, vemos Ali se prontificar a ajudá-lo, sem, no entanto, desqualificá-lo. Afinal, é o trabalho realizado pelo pai e sua devida remuneraçáo que possibilitam tanto ao pai quanto ao filho estabelecerem uma relação mediada pelo simbólico, espaço em que ambos podem ser reconhecidos.

\section{A corrida ...}

Já quase ao final do filme, o professor de Educaçáo Física da escola em que Ali estuda realiza uma seleçáo de alunos com a finalidade de escolher candidatos para uma corrida. Sem um tênis adequado, Ali náo se interessa pela competiçáo até descobrir que, entre as premiaçóes, para o terceiro lugar 
está previsto um par de tênis. Ele implora ao professor que o deixe participar da seleção, prometendo ganhar. É neste contexto que o menino constata uma possibilidade real de reparar a sua distração e devolver à irmá o seu sapato.

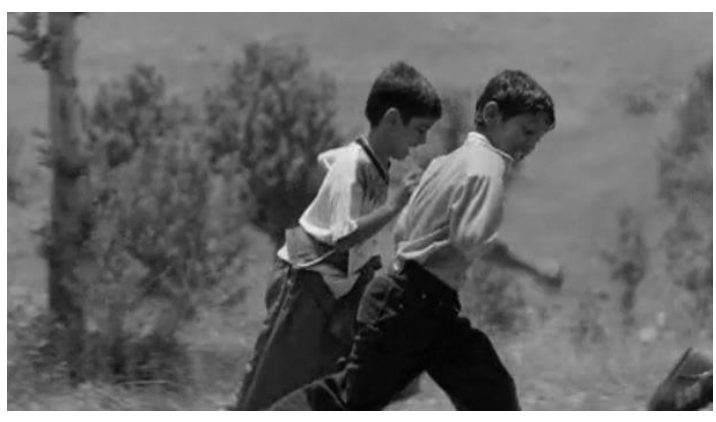

Figura 7 - Ali correndo para conquistar o terceiro lugar

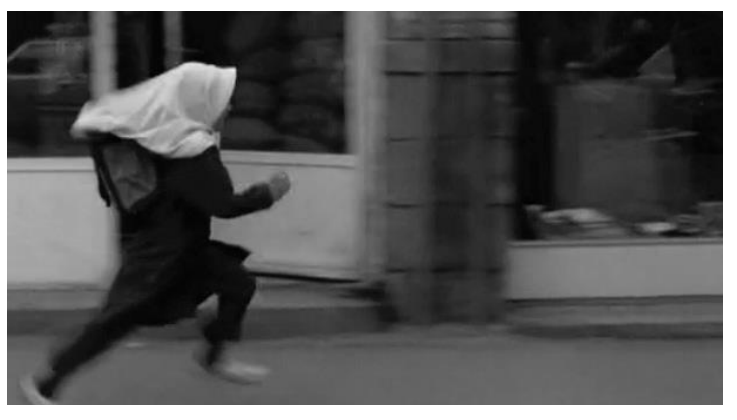

Figura 8 - Ali pensando na irmã enquanto corre

Ali é selecionado e, no decorrer da prova, podemos observar o procedimento pelo qual o diretor insere, no momento das cenas da corrida, lembranças de Ali de algumas imagens e diálogos realizados entre os irmáos na forma de flashbacks. São imagens que retratam a corrida de Zahra da escola até a troca de sapatos com o irmáo e alguns diálogos em que os irmáos conversavam sobre a perda dos sapatos e sobre a possibilidade de sua recuperação, caso Ali ganhasse o terceiro prêmio.

Interessa-nos ainda refletir porque na imagem-lembrança (flashback) que Ali tem de Zahra, no momento da corrida, o diretor não faz uso da manipulação da cor da imagem, por exemplo, por meio do uso de preto e branco ou de qualquer mudança de coloraçáo que produzisse uma diferenciaçáo do tempo presente, de modo a provocar uma espécie de transiçáo, do "mundo real" (o presente) para o "mundo do passado" (DAMASCENO 2013). Lembramos que a imagem de Ali na corrida e a imagem-lembrança de Zahra se produz com a mesma coloraçáo e sem nenhuma transição. Nesse sentido, pensamos que a imagem-lembrança de Zahra aponta para o tempo presente, produzindo uma espécie de presentificaçáo do passado.

Uma longa sequência de seis minutos, destinada ao longo trajeto da corrida, é quase toda filmada em câmera lenta, possibilitando ao espectador acompanhar o esforço sobre-humano e o desgaste físico de Ali. Como elemento da sonoplastia, o diretor opta por uma respiraçáo ofegante durante quase todo o percurso. Tais procedimentos conduzem o expectador a pensar na condiçáo resiliente de Ali diante da necessidade de vencer, bem como 
sua condiçáo desejante que se afirma durante quase todo o filme: ele precisa e deseja chegar em terceiro lugar na corrida. Procedimentos que unem Ali a Zahra, bem como, uma vez mais, nos possibilitam elevar o estatuto da corrida à presença de um ato de desejo, cujo valor ético diz de sua responsabilizaçáo pela perda dos sapatos de sua irmá.

Mesmo com a advertência do juiz da prova: "Náo empurrem os outros corredores. Vencer náo é tudo", Ali é empurrado por um companheiro de corrida, cai e, ao se levantar para retomar a corrida, perde a noçáo espaçotemporal e acaba ganhando a prova.

Ao terminar a prova, ele pergunta ao treinador: "Eu cheguei em terceiro, senhor?" E o treinador lembra que ele chegou em primeiro. Neste momento, podemos perceber a tristeza se abater no rosto de Ali, pois toda a comemoraçáo pelo seu primeiro lugar não lhe é significativa.

Ao retornar para casa, apesar de sua vitória, Ali se apresenta a irmá na condição de perdedor, uma vez que a premiação recebida não os interessa. Ele nada diz, mas novamente seus olhares se comunicam. Zahra corre para atender ao choro da irmá recém-nascida e Ali, lentamente, retira dos pés seus tênis, que, naquele momento já estão por demais furados, e podemos perceber que as bolhas e feridas tomam conta de seus pés.

Enquanto isso, o pai retorna para casa e na garupa da bicicleta podemos observar, entre outros objetos, dois pares de sapatos.

\section{Concluindo}

Por que no decorrer do texto sustentamos que a decisão de Ali se configura como um ato de desejo e apresenta uma dimensão ética? Porque ele pode se deparar com uma impossibilidade paterna e, assim, tomar uma decisáo absolutamente singular a partir da qual ele se responsabiliza. Porque ele se comprometeu com a irmá e sustentou seu compromisso, solitariamente, até o último instante, ainda que ao preço de seus pés feridos. Uma decisão que náo implicou, por parte do menino, a resposta a nenhuma demanda $\mathrm{e}$ nem tampouco em ser reconhecido. Enfim, sua liberdade de açáo implicou uma responsabilidade plena: caberia a ele e a ninguém mais, reaver os sapatos de sua irmá. Essa é a dimensáo ética do ato de Ali.

$\mathrm{O}$ que náo significa afirmar que essa escolha apresente uma dimensáo consciente. Isso porque a açáo de Ali náo foi regulada por nenhuma forma de saber, nenhum saber consciente que viesse responder pela escolha realizada, ele 
só sabia que diante da perda do único par de sapatos de sua irmá, algo deveria ser feito. Ele só sabia que era sua a responsabilidade de arcar com tal acontecimento e com a promessa realizada sem, no entanto, transferi-la ao pai. Essa é a dimensáo inconsciente que o ato de Ali sustentou em sua singularidade.

\section{Referências}

BENJAMIN, Walter. Reflexóes: a criança, o brinquedo, a educação. Trad. Marcos Vinícius Mazzari. São Paulo: Summus, 1984.

BENJAMIN, Walter. 1987. Rua de mão única. In: Obras escolhidas. Trad. R. Rodrigues Torres Filho e J. C. Martins Barbosa. Sáo Paulo: Brasiliense, 1987. v. 2.

CALLIGARIS, Contardo. Hell Brasil: notas de um psicanalista europeu viajando ao Brasil. Sáo Paulo: Escuta, 1991.

DAMASCENO, Alex. Além do flashback: estéticas audiovisuais do fenômeno da lembrança. Novos Olhares: Revista de Estudos Sobre Práticas de Recepção a Produtos Midiáticos, Sáo Paulo, v. 2, n. 1, 2013. Disponível em: <http://www. revistas.usp.br/novosolhares/article/view/57041>. Acesso em: 15 abr. 2016.

ELIAS, Janaína. Breve história do cinema iraniano. Chá-de-lima da Pérsia (Blog). Disponível em: <http://chadelimadapersia.blogspot.com. br/2014/02/breve-historia-do-cinema-iraniano.html $>$. Acesso em: 1 abr. 2016.

GEPEIAP - Grupo de Estudos e Pesquisa: Educação, Infância, Arte e Psicanálise. Arte, psicanálise e educaçáo: procedimentos estéticos no cinema e as vicissitudes da infância. Goiânia, 2016. Projeto de pesquisa.

LACAN, Jacques. Os complexos familiares na formação do indivíduo: ensaio de análise de uma função em psicologia. Rio de Janeiro: Jorge Zahar, 1993.

LACAN, Jacques. O seminário, livro 4: relaçóes de objeto. Texto estabelecido por Jacques Alain Miller. Rio de Janeiro: Jorge Zahar, 1995.

LACAN, Jacques. O seminário, livro 5: as formaçōes do inconsciente. Texto estabelecido por Jacques Alain Miller. Rio de Janeiro: Jorge Zahar, 1999.

MELEIRO, Alessandra. O novo cinema iraniano: arte e intervenção social. Sáo Paulo: Escrituras Editora, 2006. 
PIAGET, Jean. O julgamento moral na criança. 2. ed. Trad. E. Lenardon. Sáo Paulo: Summus, 1994.

ROURE, Glacy Q. de. Infância na retina: a experiência (in)visível do cinema e da infância. Avanca: Ediçóes Cine - Clube Avanca, 2014.

ROURE, Glacy Q. de. Em nome do pai. In: SOUZA, Sônia M. Gomes de (Org.). Infância, adolescência e família. Goiânia: Canône Editorial, 2001.

ROURE, Glacy Q. de; SÁ, Ana Carolina Roure M. de. A infância em abril despedaçado. Atos de Pesquisa em Educação, v. 10, n. 3, 2015.

SARMENTO, Manuel Jacinto. Palestra. In: COLÓQUIO INTERNACIONAL EDUCAÇÃO E SOCIEDADE, 2., 9 mar. 2016. Disponível em: <https://www.youtube.com/watch?v=DuxEIgoeI8E\&featu re=youtu.be $>$. Acesso em: 15 abr. 2016.

SCHLESENER, Anita Helena. Mímesis e infância: observações acerca da educação a partir de Walter Benjamin. Filosofia Unisinos, v. 10, n. 2, p. 148-156, maio-ago. 2009.

\section{Filmografia}

FILHOS do Paraíso (Bacheha-Ye Aseman). Produçáo de Majid Majidi. Irá: Buena Vista International /Miramax Films, 1997. DVD.

ONDE fica a casa do meu amigo (Khane-ye Doust Kodjast?). Produção de Abbas Kiarostami. Irã: Lume Filmes, 1987. DVD.

TAREFA de casa (Mashgh-e Shab). Produção de Abbas Kiarostami. Irã: Codec de Vídeo XviD, 1989.

O SILÊNCIO (Sokout). Produçáo de Mohsen Makhmalbaf. Irá: Cult Filmes, 1997. DVD.

A MAÇÃ (Sib). Produção de Samira Makhmalbaf. Irã: Cult Filmes, 1997. DVD.

O QUADRO negro (Takhté Siah). Produção de Samira Makhmalbaf. Irã: Clap Filmes, 1999. DVD.

CAVALO de duas pernas (Asbe Du-pa). Produção de Samira Makhmalbaf. Irã: Makhmalbaf Produçôes, 2008. DVD. 
198 Polyphonía, v. 28/1, jan.-jun. 2017

O BALĀO Branco (Badkonake Sefid). Produçáo de Jafar Panahi. Irã: Vintage Filmes, 1995. DVD.

O ESPELHO (Ayeneh). Produçáo de Jafar Panahi. Irá: Vintage Filmes, 1997. DVD.

A COR do paraíso (Rang-e Khoda). Produçáo de Majid Majidi. Irá: Europa Filmes, 1998. DVD.

TEMPO de embebedar cavalos (Zamani Barayé Masti Asbha). Produçáo de Bahman Ghobadi. Irã: Mais Filmes, 2000. DVD.

TARTARUGAS podem voar (Lakposhtha Parvaz Mikonand). Produçáo de Bahman Ghobadi. Irã: Imovision, 2004. DVD.

LIFE on the Border. Produçáo de Bahman Ghobadi. Irá, 2015.

A CANÇÃO dos pardais (Avaze Gonjeshk-Ha). Produçáo de Majid Majidi. Irá: Majid Majidi Producion, 2008. DVD.

Recebido em: 15 maio 2016.

Aceito em: 15 ago. 2016. 